\title{
Auditing Human Resources as a Method to Evaluate the Efficiency of Human Resources Functions and to Control Quality Check on HR Activities
}

\author{
Osama Shaban \\ Accounting Department, AlZaytoonah University of Jordan \\ P O Box 130, Amman 11733 Jordan \\ E-mail: Shaban_osama@hotmail.com
}

Received: December 26, 2011

Accepted: January 18, $2012 \quad$ Published: March 1, 2012

doi:10.5539/ibr.v5n3p122

URL: http://dx.doi.org/10.5539/ibr.v5n3p122

\begin{abstract}
Human Resources Audit, measures of human resource outputs and effectiveness under the given circumstances and the degree of utilization of human resource outputs. It gives feedback about the HR functions to operating managers and HR specialists. It also provides feedback about how well managers are meeting their HR duties. In short, the audit is an overall quality control check on HR activities in a division or company and an evaluation of how these activities support the organization's strategy. Evaluation of an HR function is useful to justify the existence of the department and the expenses incurred on it. If the department fails to contribute to the company's bottom line, it has no reason to function. The current study aims to evaluate the efficiency of human resources functions and to control quality check on HR Activities through human resource auditing. The scope of the study will cover areas such as; human resource functions, managerial compliance, and human resource climate. The study concluded that audit can be used as a measure to evaluate the personnel activities, climate, and compliance of an organization's policies.
\end{abstract}

Keywords: Human resource audit, Human recourses, Human resource functions

\section{Introduction}

The term human resource auditing borrows its title and rationale from accountancy, it also makes use of the system and methods of the social and scientific information. Human Resources Audit can be defined as "a systematic assessment of the strengths, limitations, and developmental needs of its existing human resources in the context of organizational performance" (Flamholtz, 1987). Human Resources Audit, "measures of human resource outputs and effectiveness under the given circumstances and the degree of utilization of human resource outputs and effectiveness under the given circumstances and the degree of utilization of the human resources in the best possible manner conducive to the organization" (AbdulAziz Arain, 2001). The audit of human assets is analytical rather than prescriptive. It aims, "to encourage professional managers and executives to develop their own ways of measuring performance against targets and objections developed from the experience and needs of their own particular unit, department and section. Executives be encouraged to revise, adapt and apply the various diagnostic methods which are best suited to their own circumstances" (Willion B. Werther \& Keith Davis, 1996).

A cost based financial manpower decision can provide a form of scenario analysis whereby various different inputs and outputs can be compared with assistance of the computer spreadsheets this analysis will organize the numerical and cost dimensions of human resources decisions in such a way which can emphasizes contingencies and probability, rather than prescription and certainty. This analysis will compel the executives to clarifying their own understanding on the way in which human capital are used and their value to the organization assessed (Boudreau \& Ramstad, 1997). Human resource audit "is one of the methods of gathering factual information of management controls and activities based on an unbiased assessment of objective evidences rather than subjective opinion" (Willion B. Werther \& Keith Davis, 1996).

Due to expansions and competition in the business trading, and manufacturing cost, the management in particular intend to reduce the cost of production without deteriorating quality, which is possible by eliminating waste, avoiding breakdowns, bottlenecks and by utilizing fully the human resources, along with other factors of production, for which human resource audit can be useful tool and assistance for better and improved management controls. It is 
an independent appraisal study of various management levels to ensure the fulfillment of the organizational objectives, policies, and procedures. Human resource audit in its scope is beyond the conventional audit. The human resource audit is more clearly defined as "a method to evaluate the efficiency of human resource at all levels throughout the organization, in order to ascertain whether sound management prevails throughout, and to recommend its effectiveness where such is not the case" (Willion B. Werther \& Keith Davis, 1996).

\subsection{Research Problem}

The research problem will try to find out whether the human resources of a certain entity is effective, and whether they are functioning properly and meeting their HR duties in order to achieve the organization's goals.

\subsection{Research Objectives}

Auditing human resource is a tool to measure the effectiveness of human resources and to provide evidence of proper management functions.

\subsection{Research Hypothesis}

- Null Hypothesis H0: Human resource audit can't be performed through the measurement of the effectiveness of the HR functions of an organization.

- Null Hypothesis H0: Human resources are not complied with the managerial policies, procedures and legal provisions.

- Null Hypothesis H0: The Human Resource Management's climate does not have an impact on employee motivation, morale and job satisfaction.

\subsection{Research Scope}

A HR audit must cover the activities of the department and extend beyond, because the people's problems are not confirmed to the HR department alone. Thus, the audit should be broad in its scope. It must evaluate the personnel function, the use of its procedures by the mangers and the impact of these activities on the employees.

Specifically, a HR audit covers the following areas:

- Audit of human resource function

- Audit of managerial compliance

- Audit of the human resource climate

\subsection{Research Methodology}

Primary data will be collected through a questionnaire, which aims to cover the research hypothesis, and forming questions which can measure the effectiveness of human resources functions. Collected data will be analyzed using the descriptive statistics (Mean and Standard deviation). Research findings and conclusions will be finally stated. Secondary data will be collected from the published books, journals, and articles in the field of research topic.

\subsection{Purpose of Human Resource Audit}

- To examine and pinpoint strength and weaknesses related to H.R. areas and skills and competencies to enable an organization to achieve its long-term and short-term goals.

- To increase the effectiveness of the design and implementation of human resource policies, planning and programs.

- To help human resource planners develop and update employment and program plans.

\subsection{Research Community}

Random samples of first class auditors have been chosen. The auditors are having the JCPA certificates, with experience not less than 10 years, and working in cogent auditing companies. The number of questionnaires distributed was 100 questionnaires. 90 of them were good for analysis.

\section{Benefits of Human Resource Audit}

Several benefit that results from an HR audit are (Willion B. Werther \& Keith Davis, 1996):

- Identification of the contributions of HR department to the organization.

- Improvement of the professional image of the HR department.

- Encouragement of greater responsibility and professionalism among members of the HR department.

- Clarification of the HR department's duties and responsibilities. 
- Stimulation of uniformity of HR policies and practices.

- Finding critical personnel problems.

- Ensuring timely compliance with legal requirements.

- Reduction of HR costs through more effective personnel procedures.

- Creation of increased acceptance of the necessary changes in the HR department, and

- A thorough review of the department's information system.

The HR manager himself or herself is interested in knowing his or her department's effectiveness. It is not that the department is infallible. Errors do happen. Policies and practices become outdated. By auditing itself, the department finds problems before they become serious. Done correctly, the evaluation process can build a strong rapport between the department and operating managers, and it can reveal outdated assumptions that can be changed to meet the department's objectives and future challenges (T.V. Rao \& Udai Pareek, 1997). Systematic assessment instills discipline in the personnel staff and encourages them to move away from intuitive techniques to more rigorous assessment of the likely benefits to be achieved. Further, "a personnel function must establish credibility with the management by justifying its programs and clearly demonstrating how it contributed to the attainment of organizational goals" (Pareek, 1997).

Nature of Human Resource Audit: A Human Resource audit "is a tool for evaluating the personnel activities of an organization. The audit may include one division or an entire company" (K. Aswathappa, 2006). It gives feedback about the HR functions to operating managers and HR specialists. It also provides feedback about how well managers are meeting their HR duties. In short, the audit is an overall quality control check on HR activities in a division or company and an evaluation of how these activities support the organization's strategy. Figure 1 illustrates this relation.

\section{Audit of Human Resource Function}

This involves audit of all HR activities. For each activity, the auditors must (i) determine the objective of each activity, (ii) identify who is responsible for it performance, (iii) review the performance, (iv) develop an action plan to correct deviation, if any between results and goals, and (v) follow up the action plan.

A questionnaire has been developed to measure the effectiveness of the HR function of an organization.

Evaluation of HR function "is useful to justify the existence of the department and the expenses incurred on it" (Pareek, 1997). If the department fails to contribute to the company's bottom line, it has no reason to function. Similarly, if the expenses incurred on the HR department far exceed its benefits to the organization, they must be pruned drastically to make the department economically viable.

\section{Audit of Managerial Compliance}

This involves audit of managerial compliance of personnel policies, procedures and legal provisions. How well are these complied with, should be uncovered by the audit so that corrective action can be taken. Compliance with the legal provisions is particularly important as any violation makes the management guilty of an offence.

\section{Audit of the Human Resource Climate}

The HRM climate has an impact on employee motivation, morale and job satisfaction. The quality of this climate can be measured by examining employee turnover, absenteeism, safety records and attitude surveys.

\subsection{Employee Turnover}

Employee turnover refers to the process of employees leaving an organization and requiring to be replaced. High turnover involves increased costs on recruitment, selection and training. In addition, high labor turnover may lead to disruption of production, problems in quality control, and difficulty in building teamwork and morale.

Certain percentage of labor turnover is unavoidable. Resignation, retirement, death and transfers do take place-causing displacement in work force. Similarly, business expansion necessitates hiring of people.

What should cause concern to the HRM is the avoidable turnover. Avoidable turnover gives an excellent measure of the HR climate as it direct attention to that, will help minimize employee turnover shall be better hiring practices, orientation training, working conditions, remuneration and benefits, and opportunities for advancement. What is significant is that a low turnover rate is worse than a high turnover if the top performers are not retained. Therefore, quality of turnover is more important than the quantity of people leaving and people joining an organization. 


\subsection{Absenteeism}

Absenteeism refers to the failure on the part of employee to report to work though they are scheduled to work. In other words, unauthorized absences constitute absenteeism. Absenteeism is computed and is expressed in terms of percentages. In a research study (muhsen A. makhamreh, 1985) found out the size he firm, the number of disputes which occurred in the firm and the workers annual, wage increase significantly affect absenteeism rates. It was also found that the size of the firm, the, number of disputes which occurred, the workers annual wage increase and the employees average years of employment in the firm are related to the turnover rate, explaining 74 percent of the variance in the rate. Moreover, absenteeism is found as a precursor to turnover in Jordanian business. Absenteeism costs money to the organization, besides reflecting employee dissatisfaction with the company.

Like employee turnover, there is avoidable and unavoidable absenteeism. Absenteeism in unavoidable when the employee himself or herself falls sick, his or her dependants at home suddenly become unwell or there is an accident inside the plant. Unavoidable absenteeism is accepted by managers and is even sanctioned by labor laws. Avoidable absenteeism arises because of nigh shifts, opportunities for moonlighting and earning extra income, indebtedness, lack of job security, job dissatisfaction and unfriendly supervision. This absenteeism needs intervention by the management. Managers must create a work environment, which will make the employees realize that it makes sense to work in the factory rather than staying at home and waste their time.

\subsection{Accidents}

Organizations maintain records relating to accidents. Accidents do cost money to the organization. They also reflect the prevailing organizational climate. The management must have a safety plan, implement it and evaluate its effectiveness.

\subsection{Attitude Surveys}

Attitude surveys are probably the most powerful indicators of organizational climate. Attitudes determine an employee's feeling to wards the organization, supervisor, peers and activities.

Attitude surveys may be conducted through face-to-face interviews but are usually done through anonymous questionnaires. The resulting information from the survey provides an invaluable insight into what employees are feeling and thinking. It can also be used to specifically address business problems associated with productivity, turnover, absenteeism, tardiness, work-group effectiveness, and industrial relations.

\section{Audit of Corporate Strategy}

Besides functions, compliance and satisfaction audit may extend to corporate strategy also. HR professionals set corporate strategy to help the organization and gain competitive advantage. By assessing the company's internal strengths and weaknesses and its external threats and opportunities, the senior management devises ways of gaining an advantage. Whether the company stresses superior marketing channels, service, innovation, low-cost production, or some other approach, HRM is affected. Understanding the strategy has strong implications for HR planning, staffing, remuneration, industrial relations, and other HR activities (William B. Werther \& Keith Davis, 1996).

\section{Audit and Personnel Research}

HR auditors depend on personnel or HR research for data. Research is understood as the systematic and goal-oriented investigation of the facts to establish a relationship between two or more phenomena. Its purposes are varied. Specifically, research can lead to an increased understanding of and improvement in HR practices. The major topics covered in HR research are:

- Wage surveys

- Effectiveness of various recruitment sources

- Effectiveness of training efforts

- Survey of supervisor's effectiveness

- Recent industrial settlements

- Job analysis

- Job satisfaction survey

- Survey of employee needs

- Attitude survey towards reward system, and

- Area of high accident frequency 
The above topics and other related areas constitute the basis for HR audit.

\section{Approaches to Human Resource Audit}

Auditors may adopt any of the five approaches for the purpose of evaluation. (i) Cooperative approach, (ii) outside authority approach, (iii) Statistical approach, (iv) Compliance approach and (v) Management by objectives (MBO) approach. It may be stated that irrespective of the approach, the data for assessment are provided by HR research.

In the comparative approach the auditors identify another company as the model. The results of their organization are compared with those of the model company. Often, the auditors use standards set by an outside consultant as benchmark for comparison of own results. This approach is called the outside authority approach. The third approach is the statistical approach. Here, statistical measures of performance are developed based on the company, existing information. Examples of such measures are absenteeism and turnover rates. These data help auditors to assess the performance. In the compliance approach, auditors review past actions to determine if those activities comply with legal requirements and company policies and procedures. A final approach is for specialists and operating managers to set objectives in their areas of responsibility. The MBO approach creates specific goals against which performance can be measured. Then the audit team researches actual performance and compares it with the objectives.

The audit program comes to an end with the preparation of the audit report. The report may be clean or qualified. The report is qualified when the HR performance contains gaps. Where gaps are observed, remedial measures are suggested. The report is clean where the performance is fairly satisfactory.

\section{Findings and Hypothesis Testing}

\subsection{The Reliability Test}

Cronpanch Alpha was used to test the reliability of the scale and it was $(0.855)$ which is good because it's higher than the accepted percent $(0.60)$. Table 5 illustrates this result.

\subsection{Hypothesis Testing}

Hypothesis (\#1):

Ho: Human resource audit can't be performed through the measurement of the effectiveness of the HR functions of an organization.

Ha: Human resource audit can be performed through the measurement of the effectiveness of the HR functions of an organization.

One sample $t$-test was used to test our hypothesis. As Table 1 shows, we found that (calculated $t=28.504$ ), which is greater than tabulated $\mathrm{t}=1.987$. According to our decision rule: Accept Ho if calculated value is less than tabulated value and reject Ho if calculated value is greater than tabulated value. So we will reject Ho and accept Ha. So that HR Audit can be performed through the measurement of the effectiveness of the HR functions of an organization.

Hypothesis (\# 2):

HO: Human resources are not complied with the managerial policies, procedures and legal provisions.

Ha: Human resources are complied with the managerial policies, procedures and legal provisions.

One sample $t$-test was used to test hypothesis (\#2). Table 2 shows that (calculated $t=27.516$ ), which is greater than tabulated t. According to our decision rule: Accept Ho if calculated value is less than tabulated value and reject Ho if calculated value is greater than tabulated value. So we will reject Ho and accept Ha. So that Human Resources are complied with the managerial policies, procedures and legal provisions.

Hypothesis (\#3):

HO: The Human Resource Management's climate does not have an impact on employee motivation, morale and job satisfaction

Ha: The Human Resource Management's climate has an impact on employee motivation, morale and job satisfaction

One sample t-test was used to test hypothesis (\#3). Table 3 shows that (calculated=21.643), which is greater than tabulated t. According to our decision rule: Accept Ho if calculated value is less than tabulated value and reject Ho if calculated value is greater than tabulated value. So we will reject Ho and accept Ha. So that The Human Resource Management's climate has an impact on employee motivation, morale and job satisfaction. 


\section{Summary \& Conclusions}

A Human Resource audit can be used as a measure to evaluate the personnel activities of an organization. It gives feedback about the HR functions to operating managers and HR specialists. It also provides feedback about how well managers are meeting their HR duties. In short, the audit is an overall quality control check on HR activities in a division or company and an evaluation of how these activities support the organization's strategy. HR Audit also gives feedback HR compliance with the legal provisions and company's policies. HR audit proved that HR climate has an impact on employee motivation, morale and job satisfaction.

So we can conclude that:

- HR Audit can be performed through the measurement of the effectiveness of the HR functions of an organization.

- Human Resources are complied with the managerial policies, procedures and legal provisions.

- The Human Resource Management's climate has an impact on employee motivation, morale and job satisfaction.

\section{References}

Abdul, A. A. (2001). Human assets accounting and human resource audit. Pakistan \& Gulf Economist, 20.

Aswathappa, K. (2006). Human Resource Management and Personnel Management (4th ed.). McGraw-hill.

Boudreau, J. W., \& Ramstad, P. M. (1997). Measuring intellectual capital: learning from financial history. Human resource Management, 36(3), 343-356. http://dx.doi.org/10.1002/(SICI)1099-050X(199723)36:3<343::AID-HRM6>3.0.CO;2-W

Eric, G. F. (1987). Future directions of Human Resource management. monograph \& Research series (Univ of California Inst of Industrial Relations).

Makhamreh, M. A. (1985). Determinants of absenteeism and turnover rates in Jordan business firms. Jordan University, 12(5), 27-34.

Pareek, U., \& Rao, T. V. (1992). Designing and managing human resource systems (2nd ed.). New Delhi: Oxford \& IBH, pp.412.

Pareek, U. (1997). Evaluation of HRD Functions (A brief note in evaluating human resource development). Jaipur: HRD Research Foundation. pp. 3-10.

Rao, T. V., \& Pareek, U. (1997). Academy of Human Resource Development.

Stone, R. J. (1995). Human Resource Management (2nd ed.). John Wiley \& Sons. pp. 542.

Werther, W. B., \& Davis, K. (1996). Human Resources and Personnel Management (5th ed.). McGraw- Hill. pp. 560.

Table 1. Test of Hypothesis (\#1)

\begin{tabular}{|c|c|c|c|}
\hline Calculated-t & t-tabulated & t-Sig & Result of Ho \\
\hline 28.504 & 1.987 & .000 & reject \\
\hline
\end{tabular}

Table 2. Test of Hypothesis (\#2)

\begin{tabular}{|c|c|c|c|}
\hline Calculated-t & t-tabulated & t-Sig & Result of Ho \\
\hline 27.516 & 1.987 & .000 & reject \\
\hline
\end{tabular}

Table 3. Test of Hypothesis (\#3)

\begin{tabular}{|c|c|c|c|}
\hline Calculated-t & t-tabulated & t-Sig & Result of Ho \\
\hline 21.643 & 1.987 & .000 & reject \\
\hline
\end{tabular}


Table 4. Case Processing Summary of Questionnaire

\begin{tabular}{|c|c|c|c|}
\hline \multicolumn{2}{|c|}{} & $\mathrm{N}$ & $\%$ \\
\hline \multirow{3}{*}{ Cases } & Valid & 90 & 100.0 \\
\cline { 2 - 4 } & Excluded $^{\mathrm{a}}$ & 0 & .0 \\
\cline { 2 - 4 } & Total & 90 & 100.0 \\
\hline
\end{tabular}

${ }^{a}$ Listwise deletion based on all variables in the procedure.

Table 5. Reliability Statistics

\begin{tabular}{|c|c|}
\hline Cronbach's Alpha & N of Items \\
\hline .855 & 35 \\
\hline
\end{tabular}

Table 6. Std. Deviation \& Mean Test One-Sample Statistics (T-Test)

\begin{tabular}{|c|c|c|c|c|}
\hline & $\mathrm{N}$ & Mean & Std. Deviation & Std. Error Mean \\
\hline $\mathrm{h} 1$ & 90 & 4.0833 & .36056 & .03801 \\
\hline $\mathrm{h} 2$ & 90 & 4.2556 & .43289 & .04563 \\
\hline $\mathrm{h} 3$ & 90 & 4.1389 & .49922 & .05262 \\
\hline
\end{tabular}

Table 7. Test Value One-Sample Test

\begin{tabular}{|c|c|c|c|c|c|c|}
\hline \multirow{2}{*}{} & \multicolumn{7}{|c|}{ Test Value =3 } & 95\% Confidence Interval of the Difference \\
\cline { 2 - 7 } & \multicolumn{7}{|c|}{ Sig. (2-tailed) } & Mean Difference & Lower & Upper \\
\cline { 2 - 7 } & $\mathrm{t}$ & $\mathrm{df}$ & .000 & 1.08333 & 1.0078 & 1.1589 \\
\hline $\mathrm{h} 1$ & 28.504 & 89 & .000 & 1.25556 & 1.1649 & 1.3462 \\
\hline $\mathrm{h} 2$ & 27.516 & 89 & .000 & 1.13889 & 1.0343 & 1.2434 \\
\hline $\mathrm{h} 3$ & 21.643 & 89 & \multicolumn{7}{c}{} \\
\hline
\end{tabular}


Table 8. Descriptive Statistics of Questionnaire

\begin{tabular}{|c|c|c|c|c|c|}
\hline Question & $\mathrm{N}$ & Minimum & Maximum & Mean & Std. Deviation \\
\hline $\mathrm{q} 1$ & 90 & 2 & 5 & 4.53 & .796 \\
\hline $\mathrm{q} 2$ & 90 & 2.00 & 5.00 & 4.2889 & .69094 \\
\hline $\mathrm{q} 3$ & 90 & 2.00 & 5.00 & 4.0556 & .90394 \\
\hline $\mathrm{q} 4$ & 90 & 2.00 & 5.00 & 3.8889 & .91730 \\
\hline $\mathrm{q} 5$ & 90 & 2.00 & 5.00 & 4.3111 & .72893 \\
\hline q6 & 90 & 2.00 & 5.00 & 4.1222 & .83232 \\
\hline $\mathrm{q} 7$ & 90 & 2.00 & 5.00 & 4.0111 & .67864 \\
\hline $\mathrm{q} 8$ & 90 & 3.00 & 5.00 & 4.2889 & .60419 \\
\hline q9 & 90 & 3.00 & 5.00 & 4.3333 & .70312 \\
\hline $\mathrm{q} 10$ & 90 & 2.00 & 5.00 & 3.8778 & .74695 \\
\hline q11 & 90 & 3.00 & 5.00 & 4.1556 & .61646 \\
\hline q12 & 90 & 1.00 & 5.00 & 3.7444 & 1.12740 \\
\hline q13 & 90 & 2.00 & 5.00 & 3.9222 & .79645 \\
\hline q14 & 90 & 2.00 & 5.00 & 4.2778 & .91219 \\
\hline $\mathrm{q} 15$ & 90 & 2.00 & 5.00 & 4.0000 & .70312 \\
\hline q16 & 90 & 2.00 & 5.00 & 3.6889 & .94387 \\
\hline q17 & 90 & 2.00 & 5.00 & 4.1444 & .93088 \\
\hline q18 & 90 & 2.00 & 5.00 & 3.8778 & .85890 \\
\hline q19 & 90 & 2.00 & 5.00 & 4.0111 & .74191 \\
\hline $\mathrm{q} 20 \mathrm{a}$ & 90 & 2.00 & 5.00 & 4.1333 & .82380 \\
\hline $\mathrm{q} 20 \mathrm{~b}$ & 90 & 2.00 & 5.00 & 3.9556 & .83345 \\
\hline $\mathrm{q} 20 \mathrm{c}$ & 90 & 2.00 & 5.00 & 3.9222 & .85101 \\
\hline q20d & 90 & 2.00 & 5.00 & 3.9111 & .77379 \\
\hline $\mathrm{q} 20 \mathrm{e}$ & 90 & 2.00 & 5.00 & 4.0000 & .63600 \\
\hline $\mathrm{q} 21$ & 90 & 3.00 & 5.00 & 4.6556 & .54383 \\
\hline $\mathrm{q} 22$ & 90 & 2.00 & 5.00 & 4.1000 & .68777 \\
\hline $\mathrm{q} 23$ & 90 & 3.00 & 5.00 & 4.0111 & .46191 \\
\hline $\mathrm{q} 24$ & 90 & 1.00 & 5.00 & 3.9889 & .74191 \\
\hline $\mathrm{q} 25 \mathrm{a}$ & 90 & 2.00 & 5.00 & 4.2111 & .75691 \\
\hline $\mathrm{q} 25 \mathrm{~b}$ & 90 & 3.00 & 5.00 & 3.8889 & .64380 \\
\hline $\mathrm{q} 25 \mathrm{c}$ & 90 & 2.00 & 5.00 & 3.8444 & .80603 \\
\hline $\mathrm{q} 26$ & 90 & 2.00 & 5.00 & 4.1444 & .74292 \\
\hline $\mathrm{q} 27$ & 90 & 2.00 & 5.00 & 4.4778 & .79645 \\
\hline q28 & 90 & 2.00 & 5.00 & 4.1444 & .72764 \\
\hline q29 & 90 & 3.00 & 5.00 & 3.8667 & .65686 \\
\hline d N (listwise) & 90 & & & & \\
\hline
\end{tabular}

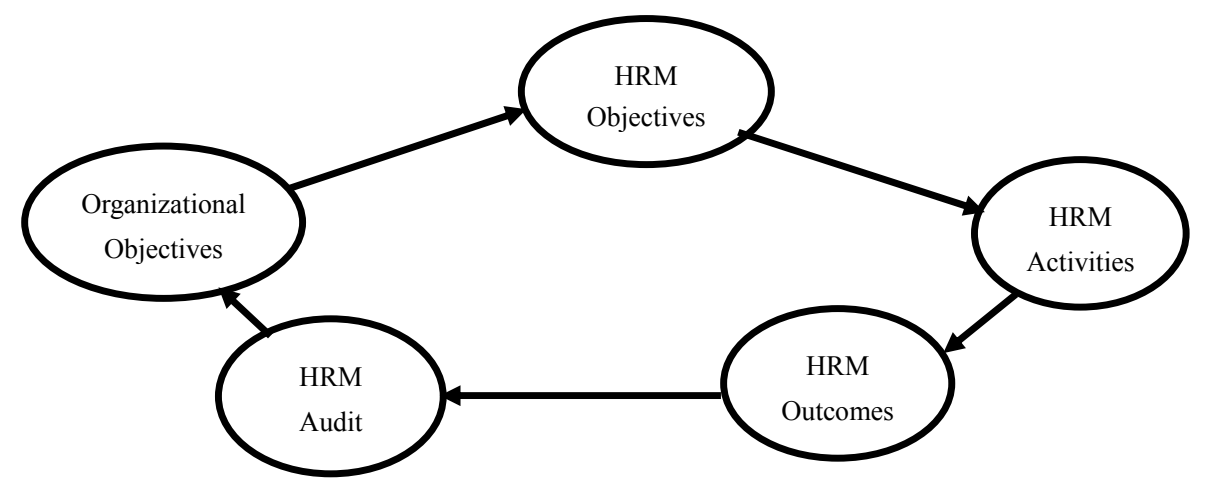

Figure 1. 